\title{
Atmosphere environment improvement in Tokyo by vehicle exhaust purification
}

\author{
H. Minoura ${ }^{1}$, K. Takahashi ${ }^{2}$, J. C. Chow ${ }^{3}$ \& J. G. Watson ${ }^{3}$ \\ ${ }^{I}$ Toyota Central R\&D Labs., Inc., Nagakute, Japan \\ ${ }^{2} J a p a n$ Environmental Sanitation Center, Kawasaki, Japan \\ ${ }^{3}$ Desert Research Institute, Reno, Nevada, USA
}

\begin{abstract}
In Japan, PM regulations in diesel automobile emissions started in 1994. Longterm measurements of suspended particulate matter $(\mathrm{SPM},<7 \mu \mathrm{m}), \mathrm{PM}_{\text {fine }}$ $(<2.1 \mu \mathrm{m})$, and $\mathrm{PM}_{\text {coarse }}(2.1$ to $7 \mu \mathrm{m})$ were obtained from an urban Kudan site in downtown Tokyo from 1994 to 2004 to evaluate the effects of emission reduction measures. A remarkable PM mass downward trend was found from 1996 onwards, especially in the $\mathrm{PM}_{\text {fine }}$ fraction, which decreased at a rate of $2.09 \mu \mathrm{g} \mathrm{m}^{-3} \mathrm{yr}^{-1}$. The decrease in $\mathrm{PM}_{\text {fine }}$ is attributable to the decreases in elemental carbon (EC) at the rate of $0.82 \mu \mathrm{g} \mathrm{m}^{-3} \mathrm{yr}^{-1} . \mathrm{PM}_{\text {fine }}$ EC concentrations at the roadside Noge site shows a threefold faster downward trend, at the rate of $2.56 \mu \mathrm{g} \mathrm{m}^{-3} \mathrm{yr}^{-1}$. This decrease is consistent with fleet penetration of engines and fuels that complied with a stringent Japanese emission reduction limit which began to take effect in 1994. It is apparent that vehicle emission reduction contributed to air quality improvement in Tokyo. The levelling off of the EC reductions since 2005 may be explained by the results from the carbon isotope $\left({ }^{14} \mathrm{C}\right)$ analysis, which suggested contributions from biomass combustion sources in addition to vehicle emissions in downtown Tokyo.
\end{abstract}

Keywords: Japan, Tokyo, trends, particulate matter, chemical composition, elemental carbon, biomass combustion.

\section{Introduction}

Atmospheric particulate matter (PM) is important for health, visibility, and climate [1-3]. Vehicle emissions are major contributors to PM, irrespective of recent advances in emission reduction technology [4]. Figure 1 shows a trend in 
the number of vehicles and fuel consumption over the last 50 years. Passenger and light car numbers increased rapidly from the 1960s to the early 1990s, while truck numbers leveled after 1980. Passenger car and truck numbers decreased after 2000, but fuel-use decreased more rapidly after 2000, especially for diesel fuel. Diesel fuel consumption increased from 1987 to 2000, irrespective of the steady truck numbers, implying the increase of average kilometers traveled by each vehicle, which corresponds to the growth in trip length per year [5].
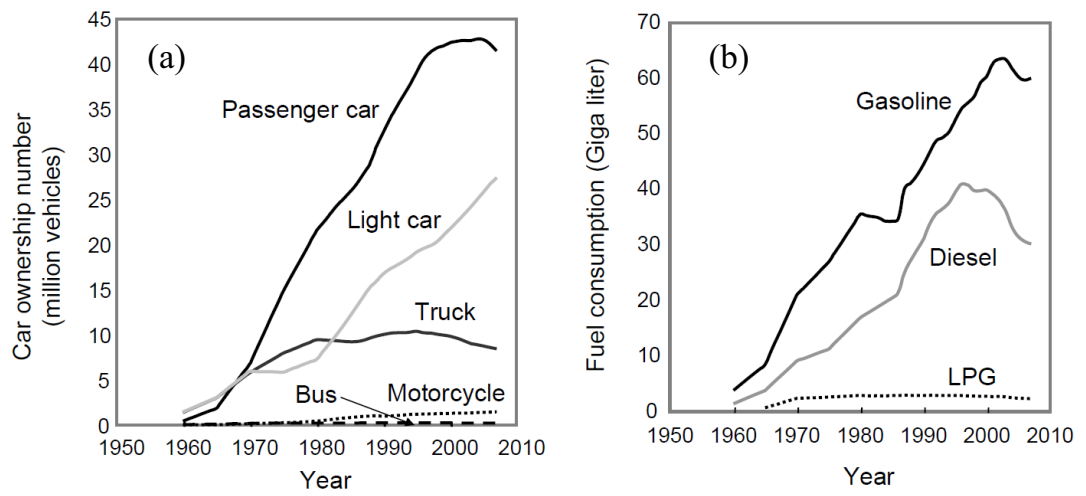

Figure 1: $\quad$ Yearly trends of Transport in Japan (a) the car ownership number for each sector, (b) the fuel consumption (data source: Ministry of Land, Infrastructure, Transport and Tourism).

The ratio of diesel passenger cars in Japan is very low. Figure 2 shows a trend for nitrogen oxides $\left(\mathrm{NO}_{\mathrm{x}}\right)$ and $\mathrm{PM}$ emissions from on-road vehicles in the Tokyo area [6]. This decreasing trend suggests the effectiveness of the action plan: "NO diesel car operation," established in 1999 by the Governor of Tokyo, which prohibits the operation of old vehicles (trucks $>7$ years) in Tokyo [7].

Diesel engines emit high $\mathrm{NO}_{\mathrm{x}}$ and low $\mathrm{PM}$ during high-temperature combustion with the reverse pattern at low temperatures [8]. $\mathrm{NO}_{\mathrm{x}}$ limitations were more stringent than those for PM owing to high ambient nitrogen dioxide $\left(\mathrm{NO}_{2}\right)$ levels detected in the 1970s and early 1980s. PM emission limits were lowered in the 1990s, with new limits for long-term regulation (the most stringent in the world) anticipated since 2005 [9]. Figure 3 shows that the Japanese government proceeded to more stringent $\mathrm{NO}_{\mathrm{x}}$ than $\mathrm{PM}$ regulations, while historically more stringent $\mathrm{PM}$ than $\mathrm{NO}_{\mathrm{x}}$ were regulated in the U.S. and Europe. Rapid decrease in PM emissions (2003 - 2005), shown in Figure 2(b), reflect: 1) the new short term regulation, enforced in 2003; and 2) the decrease in on-road truck numbers (Figure 1(a)).

SPM (suspended particulate matter) refers to the Japanese PM standard for particles sampled through an inlet having $0 \%$ transmission for particles with $10 \mu \mathrm{m}$ aerodynamic diameter; equivalent to a $50 \%$ cut-point of $\mathrm{PM}_{7}$. Annual average SPM in Tokyo has exceeded $50 \mu \mathrm{g} \mathrm{m}^{-3}$ from 1990-1997. Approximately $80 \%$ of the 49 monitoring stations exceeded the 24 -hour standard 


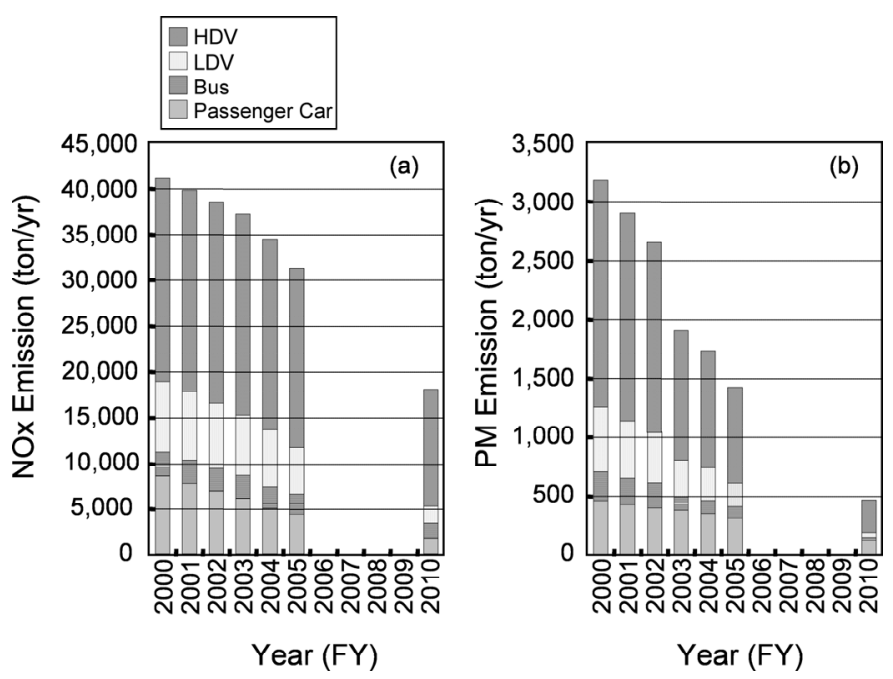

Figure 2: Vehicle emission trends for: (a) $\mathrm{NO}_{x}$, expressed as $\mathrm{NO}_{2}$; and (b) $\mathrm{PM}_{\text {coarse }}$ (?) for the Tokyo metropolitan area. HDV: Heavy-duty diesel vehicles; LDV: Light-duty diesel vehicles. Values before 2005 was based on the actual situation, and value of 2010 was estimated in consideration of automobile substitution.

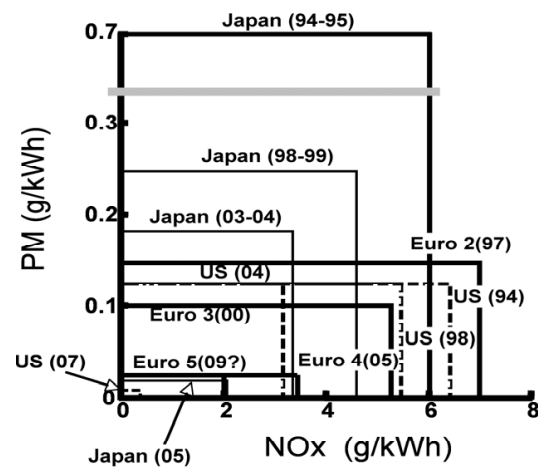

Figure 3: World emission regulation trend for heavy duty vehicle.

of $100 \mu \mathrm{g} \mathrm{m}^{-3}$ (98 $8^{\text {th }}$ percentile) from 1973 when monitoring was started until 1998. If engine exhaust is a large contributor to SPM, SPM levels in Japan would decrease as vehicle emission limits took place.

Ten years (1994-2006) of PM mass and chemical concentrations obtained from two sites in Tokyo traffic-dominated environment are examined. Special attention is given to the organic carbon (OC) and elemental carbon (EC) fractions (major PM constituents in vehicular emissions [10, 11]), along with six water-soluble ionic species. The objectives of this paper are: 1) to evaluate 
changes in vehicle contributions; and 2) to establish relationships between vehicle emissions and long-term trends in ambient concentrations.

\section{Experimental method}

As shown in Figure 4, the urban Kudan monitors were placed on the rooftop of a 10 -story building about $30 \mathrm{~m}$ above ground level in downtown Tokyo, with heavily travelled roadways nearby. The site is surrounded by office buildings and large open spaces, including the Yasukuni Shrine and the Imperial Palace. The nearby Chiyoda $(1.9 \mathrm{Km})$ and Hibiya $(2.4 \mathrm{Km})$ sites are compliance monitors operated by the Tokyo metropolitan government. The Noge monitors were located at the busy roadside of Ring 8 with a traffic volume of $\sim 92,000$ vehicles/day on weekdays, including $13 \%$ heavy-duty diesel-fuelled vehicles.

Table 1 shows the measurements for both in situ continuous hourly SPM by beta attenuation monitor (BAM) and two-week integrated SPM filter measurements by Andersen Cascade impactor acquired at the Kudan site. There may be some differences when comparing OC and EC between the Kudan and Noge sites, since two different carbon analysis protocols are used, but it will not affect the 10-year trend. All thermal carbon methods are operationally defined. Watson et al. [12] summarize nearly 20 different methods and 40 different intercomparison studies that show varying degrees of agreement worldwide.

Water-soluble chloride $\left(\mathrm{Cl}^{-}\right)$, nitrate $\left(\mathrm{NO}_{3}{ }^{-}\right)$, sulphate $\left(\mathrm{SO}_{4}{ }^{-}\right)$, sodium $\left(\mathrm{Na}^{+}\right)$, potassium $\left(\mathrm{K}^{+}\right)$, and ammonium $\left(\mathrm{NH}_{4}^{+}\right)$were measured by ion chromatography after extraction of a portion of the quartz-fiber filter in distilled-deionized water [13]. Five field blanks were analyzed for carbon and ions with each batch of 100 ambient samples. Blank values were averaged and subtracted from the ambient samples prior to normalization to the sample volume.

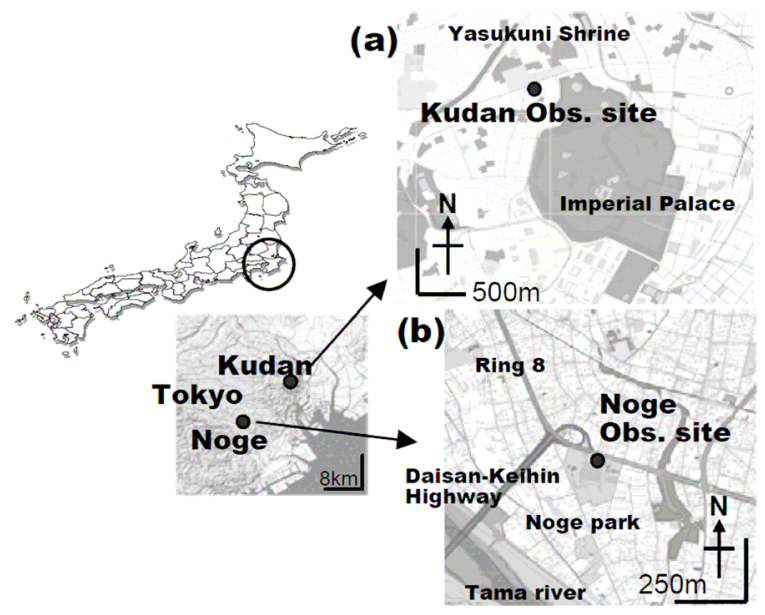

Figure 4: Sampling locations in Tokyo for the: (a) urban site at Kudan; and (b) roadsite at Noge. 
Table1: Summary of ambient measurements at the urban Kudan and roadside Noge sites in Tokyo between 1994 and 2004.

\begin{tabular}{|c|c|c|c|c|c|c|}
\hline $\begin{array}{l}\text { Sampling } \\
\text { Site }\end{array}$ & PMSize & Instruments & Observables & $\begin{array}{l}\text { Measurement } \\
\text { Method }\end{array}$ & $\begin{array}{l}\text { Sampling } \\
\text { Duration and } \\
\text { Frequency }\end{array}$ & $\begin{array}{l}\text { Measurement } \\
\text { Periods }\end{array}$ \\
\hline \multirow{4}{*}{$\begin{array}{c}\text { Kudan } \\
\text { (urban } \\
\text { background) }\end{array}$} & $\mathrm{SPM}\left(-\mathrm{PM}_{7}\right)$ & $\begin{array}{c}\text { Beta attenuation monitor } \\
\text { (BAM; Model DUB-12, Towa } \\
\text { DKK Corp. Ltd., Tokyo, Japan) }\end{array}$ & Mass & beta attenuation & $\begin{array}{c}1 \mathrm{hr}, \\
24 \text { samples/day, } \\
365 \text { days/yr }\end{array}$ & $\begin{array}{c}6 / 1 / 1994 \text { through } \\
3 / 31 / 2006\end{array}$ \\
\hline & \multirow{3}{*}{$\begin{array}{l}\mathrm{PM}_{\text {fine }}(<2.1 \mu \mathrm{mm}) \\
\text { and } \\
\mathrm{PM}_{\text {coarse }}(2.1-7 \mu \\
\mathrm{m})\end{array}$} & \multirow{3}{*}{$\begin{array}{c}\text { Andersen Cascade Impactor } \\
\text { Sampler (Model AN-200, } \\
\text { Tokyo Dylec, Tokyo, Japan) } \\
\text { with quartz-fiber filters ( } 2500 \\
\text { QAT-UP, Pall Sciences, Ann } \\
\text { Arbor, MI, USA) }\end{array}$} & Mass & gravimetric analysis & \multirow{3}{*}{$\begin{array}{c}2 \text { weeks, } \\
26 \text { samples/yr }\end{array}$} & \multirow[b]{2}{*}{$\begin{array}{l}\text { 6/1/1994 through } \\
\text { 3/31/2006 }\end{array}$} \\
\hline & & & $\begin{array}{c}\text { Organic carbon }(\mathrm{OC}) \text {, } \\
\text { Elemental Carbon } \\
\text { (EC), and Total Carbon } \\
\text { (TC) }\end{array}$ & $\begin{array}{l}\text { OC: } 100 \% \text { He at } 650^{\circ} \\
\text { C for } 8 \text { minutes } \\
\text { TC: } 90 \% \mathrm{He} / 10 \% \mathrm{O}_{2} \text { at } \\
9500^{\circ} \mathrm{C} \text { for } 5 \text { minutes }\end{array}$ & & \\
\hline & & & $\begin{array}{c}\text { Chloride }(\mathrm{Cl}) \text {, Nitrate } \\
\left(\mathrm{NO}_{3}^{-}\right) \text {, Sulfate }\left(\mathrm{SO}_{4}^{-}\right) \text {, } \\
\text { Sodium }\left(\mathrm{Na}^{+}\right) \text {, } \\
\text { Potassium }\left(\mathrm{K}^{+}\right) \text {, and } \\
\text { Ammonium }\left(\mathrm{NH}_{4}^{+}\right)\end{array}$ & ion chromatography & & $\begin{array}{l}\text { 3/31/1997 through } \\
3 / 31 / 2006\end{array}$ \\
\hline $\begin{array}{c}\text { Noge } \\
\text { (roadside) }\end{array}$ & $\mathrm{PM}_{2.5}$ & $\begin{array}{l}\text { Ambient carbon particulate } \\
\text { monitor (Model } 5400 \text {. } \\
\text { Rupprecht \& Patashnick, } \\
\text { Albany, NY, USA) }\end{array}$ & $\mathrm{OC}$ and $\mathrm{EC}$ & $\begin{aligned} \mathrm{OC}: & 340^{\circ} \mathrm{C} \text { for } 13 \\
& \text { minutes } \\
\mathrm{EC}: & 750^{\circ} \mathrm{C} \text { for } 8 \\
& \text { minutes }\end{aligned}$ & $\begin{array}{c}2 \mathrm{hr}, \\
12 \text { samples/day, } \\
365 \text { days/yr }\end{array}$ & $\begin{array}{l}12 / 8 / 2002 \text { through } \\
9 / 5 / 2004\end{array}$ \\
\hline
\end{tabular}

\section{Results}

\subsection{PM mass concentrations}

Figure 5 shows that before 2000, elevated SPM concentrations were frequently observed in summer (June - August) and winter (December - February) at the urban Kudan site. High concentrations in summer may be attributed to the photochemically generated $\mathrm{SO}_{4}{ }^{2}$. Elevated SPM were also found during winter due to the shallow surface layer that persists for several hours after sunrise. Annual SPM mass concentrations are consistently in the range of $51-53 \mu \mathrm{g} \mathrm{m}^{-3}$ between 1994 and 1997, with a $25 \%$ decrease from $47 \mu \mathrm{g} \mathrm{m}^{-3}$ in 1998 to $36 \mu \mathrm{g}$ $\mathrm{m}^{-3}$ in 1999 . This decrease was also found at the 27 roadside monitoring sites

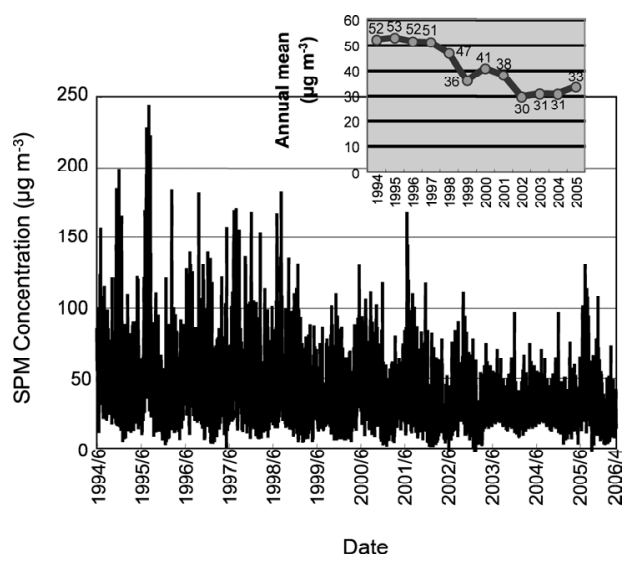

Figure 5: Hourly and annual (inset) arithmetic average SPM mass concentrations by beta attenuation monitor (BAM) at the urban Kudan site from 1994 through 2006. 


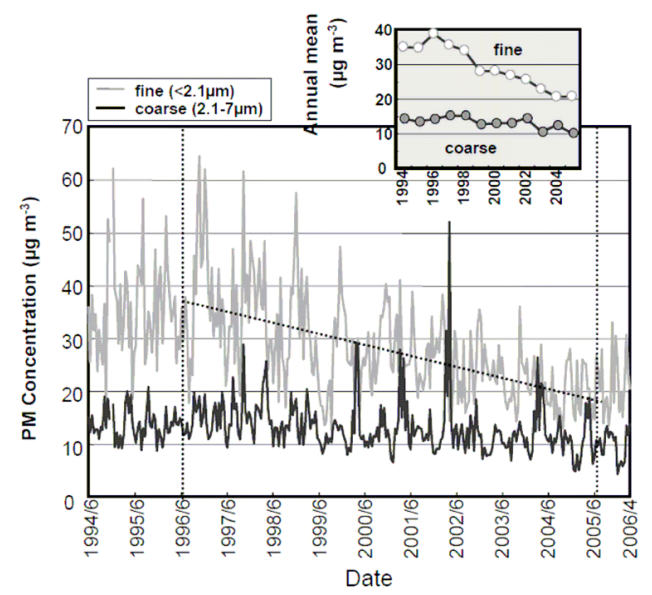

Figure 6: Two-week and annual average (inset) $\mathrm{PM}_{\text {fine }}(<2.1 \mu \mathrm{m})$ and $\mathrm{PM}_{\text {coarse }}(2.1-7 \mu \mathrm{m})$ mass concentrations at the Kudan site from 1994 to 2006. The dashed line is a least-squares fit to the annual averages for nine years, which shows a decrease of $2.09 \mu \mathrm{g} \mathrm{m}^{-3} \mathrm{yr}^{-1}$ for $\mathrm{PM}_{\text {fine }}$ starting September 1996.

operated by the Tokyo metropolitan government [13]. Mean wind speeds increased during summer and winter of 1999, and it is possible that there was greater dispersion.

As shown in Figure 6, the long-term improvement in SPM levels is due to the reductions in the $\mathrm{PM}_{\text {fine }}$ fraction at a rate of $2.09 \mu \mathrm{g} \mathrm{m} \mathrm{m}^{-3}$. $\mathrm{PM}_{\text {coarse }}$ concentrations did not change over the 10-year period, reflecting similar influence from road dust or marine aerosol. A few spikes in $\mathrm{PM}_{\text {coarse }}$ were found during springtime, probably reflecting contributions from Asian dust storms [1416], which are common occurrences in Japan.

\subsection{PM carbon trends}

Figure 7 shows that EC was much higher than $\mathrm{OC}$ in $\mathrm{PM}_{\text {fine }}$ than $\mathrm{PM}_{\text {coarse }}$ fractions, suggesting the dominance of diesel engines (MOE manual, 1997). Average EC to total carbon (TC; sum of EC and OC) ratio was 0.76 in $\mathrm{PM}_{\text {fine }}$ and 0.62 in $\mathrm{PM}_{\text {coarse }}$. The ratio of $\mathrm{EC}$ to $\mathrm{TC}$ also decreased, indicating that these primary emissions were decreasing more rapidly than $\mathrm{OC}$, some of which comes from conversion of gases to particles. The high $\mathrm{PM}_{\text {fine }} \mathrm{EC} / \mathrm{TC}$ ratio is similar to other measurements reported in Japan [17, 18] and Hong Kong, China. Compared to the thermal/optical method (Chow et al., 1993), Takahashi et al. [19] found overestimation of EC by $41 \%$ in $\mathrm{PM}_{\text {fine }}$ and by $104 \%$ in $\mathrm{PM}_{\text {coarse }}$, but no difference was found for TC.

The decrease in EC/TC ratio is consistent with diesel vehicles becoming more efficient combustors. $\mathrm{PM}_{\text {fine }}$ carbon started to decrease after 1996 at a rate of $0.20 \mu \mathrm{g} \mathrm{m}^{-3} \mathrm{yr}^{-1}$ for OC and $0.82 \mu \mathrm{g} \mathrm{m}^{-3} \mathrm{yr}^{-1}$ for EC based on linear regression. 

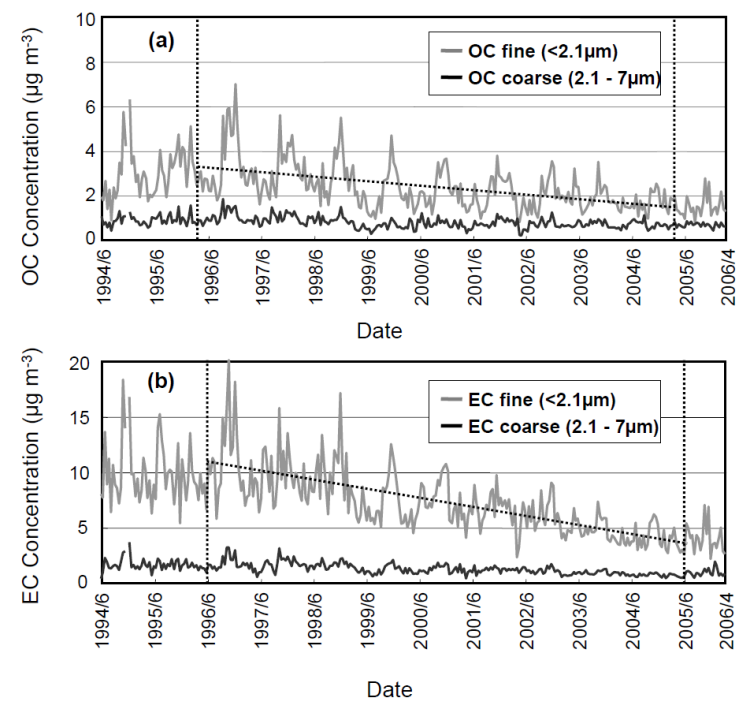

Figure 7: Temporal variations in $\mathrm{OC}$ and $\mathrm{EC}$ concentrations at the Kudan site. The reduction rate of each component since 1996, shown by the dashed line, is $0.20 \mu \mathrm{g} \mathrm{m}-3 \mathrm{yr}^{-1}$ for $\mathrm{OC}$ and $0.82 \mu \mathrm{g} \mathrm{m}-3 \mathrm{yr}^{-1}$ for EC.

These decreases reflect the fleet penetration of lower emitting diesel engines mandated by the 1994 for $\mathrm{NO}_{\mathrm{x}}$ and PM.

The long-term EC trend at the urban Kudan site is consistent with the shorterterm trend found at the roadside Noge site. The Noge site reported a threefold higher EC reduction rate of $2.56 \mu \mathrm{g} \mathrm{m}^{-3} \mathrm{yr}^{-1}$ (Figure 8), as compared to the Kudan site $\left(0.82 \mu \mathrm{g} \mathrm{m}^{-3} \mathrm{yr}^{-1}\right)$. Even though this rapid decrease may reflect the

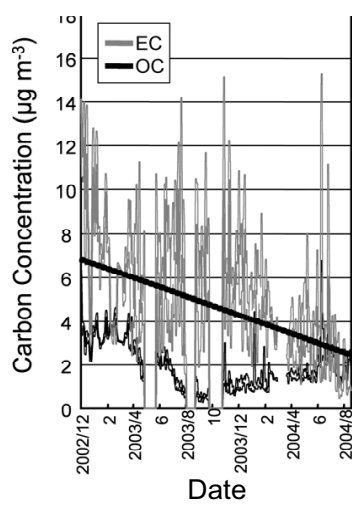

Figure 8: $\quad$ Two-hour averaged OC and EC concentrations from the R\&P5400 carbon monitor at the Noge site from 12/1/2002 through 8/31/2004. The dotted line shows EC concentrations decreasing at a rate of $2.56 \mu \mathrm{g} \mathrm{m}^{-3} \mathrm{yr}^{-1}$. 
phase in of low-emitting diesel vehicles, this value may be biased owing to the shorter measurement period, as well as different carbon measurement method used at the Noge site.

\subsection{Chemical composition}

Figure 9 shows that water-soluble ions contributed 38\% (including 32\% from $\mathrm{NO}_{3}{ }^{-}, \mathrm{SO}_{4}{ }^{\prime}$, and $\mathrm{NH}_{4}{ }^{+}$) to $\mathrm{PM}_{\text {fine }}$ for the nine years from $1994-2005$, with $26 \%$ attributed to TC. Long-term trends in $\mathrm{PM}_{\text {fine }}$ components are more apparent for $\mathrm{EC}$, to a much lesser extent for $\mathrm{OC}, \mathrm{NO}_{3}{ }^{-}, \mathrm{NH}_{4}{ }^{+}$, and $\mathrm{Cl}^{-}$, but are unclear for $\mathrm{SO}_{4}{ }^{=}$. A large change in the $\mathrm{EC}$ reduction rate was found beginning 2002 to 2004, which varied from $-0.49 \mu \mathrm{g} \mathrm{m}^{-3} \mathrm{yr}^{-1}$ to $-1.09 \mu \mathrm{g} \mathrm{m}^{-3} \mathrm{yr}^{-1}$. As expected, material balance in $\mathrm{PM}_{\text {coarse }}$ shows $9 \%$ for sea salt $\left(\mathrm{Na}^{+}\right.$and $\left.\mathrm{Cl}^{-}\right), 21 \%$ for other ions (i.e., $\mathrm{NO}_{3}{ }^{-}, \mathrm{SO}_{4}{ }^{2}, \mathrm{NH}_{4}{ }^{+}$, and $\mathrm{K}^{+}$), $14 \%$ for $\mathrm{TC}$, and $56 \%$ in the "other" category. This "other" category can probably be attributed to the abundant geological material (i.e., metal oxides) found in $\mathrm{PM}_{\text {coarse }}$.

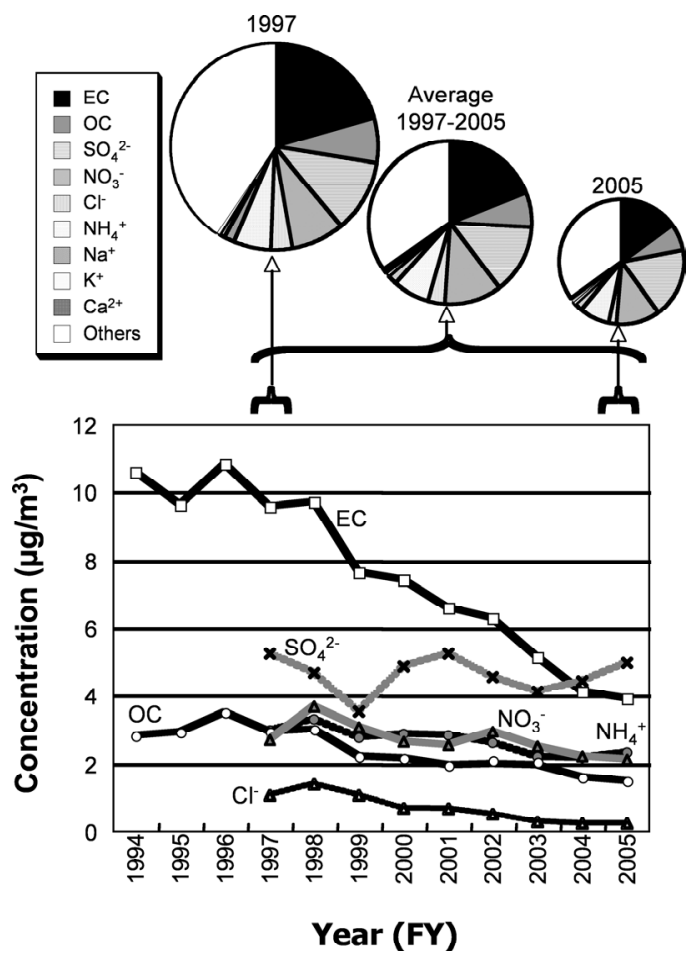

Figure 9: Annual variations of $\mathrm{PM}_{\text {fine }}$ composition for two-week impactor samples at the urban Kudan site from 1994 through 2005. The "others" category in the pie charts includes unmeasured species, such as mineral oxides in fugitive dust and oxygen and hydrogen associated with organics. 


\subsection{Other carbon sources}

Seasonal variations in the $\mathrm{PM}_{\text {fine }} \mathrm{EC}$ were examined to investigate the decrease in EC reduction ratios during $2004-2005$. Figure 10 shows a monthly increase in EC concentrations from October to December, partially attributed to the atmospheric stability during winter.

Because ${ }^{14} \mathrm{C}$ is only present in contemporary carbon, not in fossil fuels, the influence of biomass burning is investigated [20]. Figure 11 shows that elevated

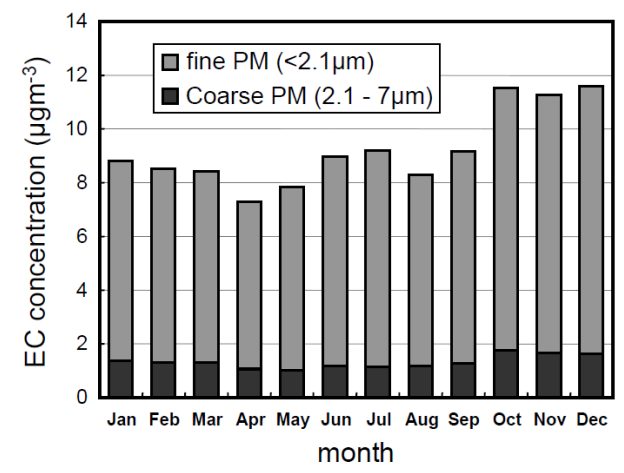

Figure 10: Seasonal variation in $\mathrm{PM}_{\text {fine }}$ and $\mathrm{PM}_{\text {coarse }} \mathrm{EC}$ concentrations for two-week impactor samples at the urban Kudan site from 1994 through 2005.

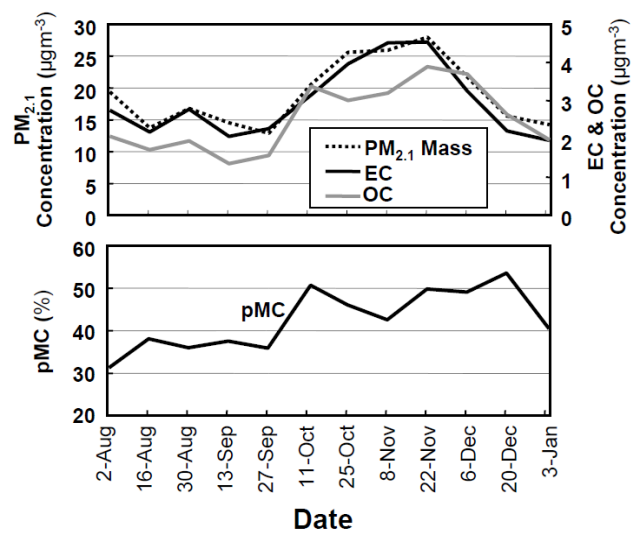

Figure 11: Temporal variation in the fine particle $\left(\mathrm{PM}_{2.1}\right)$ mass, $\mathrm{EC}$, and $\mathrm{OC}$ concentrations (upper), and the percent of modern carbon, "pMC" (lower). The pMC was obtained on the basis of the isotope ratio of ${ }^{14} \mathrm{C} /{ }^{12} \mathrm{C}$. A pMC value of $100 \%$ means that all of the carbon is of biomass origin, and a $\mathrm{pMC}$ value of $0 \%$ means that all of the carbon is of fossil fuel combustion. The data for both charts was obtained from two-week impactor samples at the Kudan site in 2004. 
$\mathrm{PM}_{\text {fine }}$ mass and carbon concentrations between October and November correspond to an increasing trend of pMC (the percentage of modern carbon in total carbon), suggesting the influence of vegetative burning. During 2004, as major improvements in vehicle engine technology and emission reduction was recognized [21], it became clear that vegetative combustion may account for 30 $50 \%$ of carbonaceous aerosol in Tokyo. Tobacco smoke and burning of solid wastes in open dumps may be major sources, but the investigation of the sources of vegetative burning are underway.

\section{Conclusions}

Ambient SPM $\left(\sim \mathrm{PM}_{7}\right)$ concentrations have decreased from 1994 to 2006 at the urban Kudan site, near heavily travelled roadways in Tokyo. This trend is mainly due to reductions in the $\mathrm{PM}_{\text {fine }}(<2.1 \mu \mathrm{m})$ size fraction, that decreased at a rate of $2.09 \mu \mathrm{g} \mathrm{m}^{-3} \mathrm{yr}^{-1}$ after 1996. The decrease in PM mass concentrations corresponded to the introduction of new diesel engine technology in 1994 with stringent limits on PM emission rates. Most of the reductions can be attributed to the decrease in $\mathrm{PM}_{\text {fine }} \mathrm{EC}\left(0.82 \mu \mathrm{g} \mathrm{m}^{-3} \mathrm{yr}^{-1}\right)$ and $\mathrm{OC}\left(0.20 \mu \mathrm{g} \mathrm{m}^{-3} \mathrm{yr}^{-1}\right)$. It became clear that vehicle emission reduction contributed to air quality improvement in Tokyo. By examining a carbon isotope $\left({ }^{14} \mathrm{C} /{ }^{12} \mathrm{C}\right)$ ratio on selected samples, it is found that biomass combustion sources could contribute to the slowed decreasing trend in EC from 2004 to 2005. More research is underway to identify and quantify PM source contributions from biomass and fossil fuel combustion.

\section{References}

[1] Vedal, S. 1997. Critical Review - Ambient particles and health: Lines that divide. Journal of the Air \& Waste Management Association 47 (5), 551-581.

[2] Watson, J.G. 2002. Visibility: Science and regulation. Journal of the Air \& Waste Management Association 52 (6), 628-713

[3] Jacobson, M.Z. 2002. Analysis of aerosol interactions with numerical techniques for solving coagulation, nucleatin, condensation, dissolution, and reversible chemistry among multiple size distributions. Journal of Geophysical Research 107 (D19), AAC 2-1-AAC 2-23, DOI:10.1029/2001JD002044.

[4] Chow, J.C., Watson, J.G. 2002. $\mathrm{PM}_{2.5}$ carbonate concentrations at regionally representative Interagency Monitoring of Protected Visual Environment sites. Journal of Geophysical Research 107 (D21), ICC 6-1ICC 6-9, doi: 10.1029/2001JD000574.

[5] MLITT, http://www.mlit.go.jp/statistics/index.html

[6] Tokyo Environmental White Paper 2004, 2005. Ed. The Bureau of the Environment, Tokyo Metropolitan Government, pp.140.

[7] Environment of Tokyo, http://www2.kankyo.metro.tokyo.jp/jidousya /diesel/ 
[8] Lloyd, A.C., Cackette, T.A. 2001. 2001 Critical Review — Diesel engines: Environmental impact and control. Journal of the Air \& Waste Management Association 51 (6), 809-847.

[9] Karim and Ohno, 2000, www.env.go.jp/air/car/gas_kisei.html

[10] Watson, J.G., Chow, J.C. 2001. Ambient air sampling. In Aerosol Measurement: Principles, Techniques, and Applications, Second Edition, 2nd Edition, Baron, P., Willeke, K., editors. John Wiley \& Sons, New York, NY, pp. 821-844.

[11] Watson, J.G., Chow, J.C., Fujita, E.M. 2001. Review of volatile organic compound source apportionment by chemical mass balance. Atmospheric Environment 35 (9), 1567-1584.

[12] Watson, J.G., Chow, J.C., Chen, L.-W.A. 2005. Summary of organic and elemental carbon/black carbon analysis methods and intercomparisons. Aerosol and Air Quality Research 5 (1), 69-102.

[13] Chow, J.C., Watson, J.G. 1999. Ion chromatography in elemental analysis of airborne particles. In Elemental Analysis of Airborne Particles, Vol. 1, Landsberger, S., Creatchman, M., editors. Gordon and Breach Science, Amsterdam, pp. 97-137.

[14] Fu, F.F., Watanabe, K., Yabuki, S., Akagi, T. $2004 . \quad$ Seasonal characteristics of chemical compositions of the atmospheric aerosols collected in urban seaside area of Tokaimura, eastern central Japan. Journal of Geophysical Research 109 (D20212), doi:10.1029/ 2004JD004712.

[15] Iino, N., Kinoshita, K., Tupper, A.C., Yano, T. 2004. Detection of Asian dust aerosols using meteorological satellite data and suspended particulate matter concentrations. Atmospheric Environment 38 (40), 6999-7008.

[16] Ma, C.J., Tohno, S., Kasahara, M. 2005. A case study of the size-resolved individual particles collected at a ground-based site on the west coast of Japan during an Asian dust storm event. Atmospheric Environment 39 (4), 739-747.

[17] Kadowaki, S. 1990. Characterization of carbonaceous aerosols in the Nagoya urban area 1. Elemental and organic carbon concentrations and the origin of organic aerosols. Environmental Science \& Technology 24, 741-744.

[18] Ohta, S., Okita, T. 1994. Measurements of particulate carbon in urban and marine air in Japanese areas. Atmospheric Environment 18, 2439-2445.

[19] Takahashi, K., Minoura, H., Sakamoto, K., 2008. Chemical composition of atmospheric aerosols in the general environment and around a trunk road in the Tokyo metropolitan area. Atmospheric Environment 42, 113125.

[20] Takahashi, K., Hirabayashi, M., Tanabe, K., Shibata, Y., Nishikawa, M., Sakamoto, K., 2007. Radiocarbon Content in Urban Atmospheric Aerosols. Water Air and Soil Pollution, 185, 305-310.

[21] Ministry of the Environment, The study meeting report of gross weight reduction measures environmental improvement effect, http://www.env.go.jp/press/press.php?serial $=6432$ 